\title{
PENGARUH SERBUK BAN BEKAS SEBAGAI CAMPURAN AGREGAT HALUS PADA CAMPURAN ASPAL POROUS
}

\author{
Nunung Martina ${ }^{1, *)}$, Muhammad Fathur Rouf Hasan ${ }^{1, *)}$, Yanuar Setiawan ${ }^{1, *)}$ \\ ${ }^{1)}$ Jurusan Teknik Sipil Politeknik Negeri Jakarta \\ Jl. Prof. G.A. Siwabessy Kampus UI Depok, Indonesia 16425 \\ ${ }^{*}$ Email: nunung.martina@sipil.pnj.ac.id,rouf@sipil.pnj.ac.id, \\ dan yanuar.setiawan@sipil.pnj.ac.id
}

\begin{abstract}
The porous asphalt mixture is a new generation of flexible pavement that is able to pass water in the upper layer (wearing course) both vertically and horizontally. The porous asphalt layer effectively provides more safety, especially when it rains to avoid aquaplaning which causes roughness of the surface to be more rough. Therefore, at this time there are many studies on the use of alternative materials to replace the limited natural materials with materials that can be utilized. The results showed that porous asphalt mixture with used tire crumb as a fine aggregate mixture had an increase in flow value of $6.32 \%$ with a decrease in stability value by 27.52\% and a decrease Marshall Quotient value at 31.82\%. The testing of roughness is increased by $17.71 \%$ and Mu-Meter $24.14 \%$. This research is effective in overcoming environmental problems which include processing tire waste of 3.03 tons for $1 \mathrm{~km}$ of road pavement construction work.
\end{abstract}

Kata Kunci : tire crumb, aquaplaning, porous asphalt, Mu-Meter

\section{PENDAHULUAN}

Pertumbuhan ekonomi yang semakin pesat serta bonus demografi berdampak pada mobilitas manusia dan barang. Berdasarkan data Badan Pusat Statistik (BPS) perkembangan jumlah kendaraan bermotor semakin meningkat, pada tahun 2010 sekitar 76.907.127 dan mengalami peningkatan drastis menjadi 138.556.669 pada tahun 2017. Perkembangan jumlah kendaraan bermotor berdampak pada jalur transportasi dan mengharuskan memiliki infrastruktur jalan yang mumpuni. Jalan raya melayani hampir $80 \%$ angkutan barang dan orang (Sugiyanto, 2008), sehingga membutuhkan lapisan perkerasan yang memadai untuk meningkatkan kekuatan, tingkat kenyamanan, dan keselamatan agar dapat berfungsi dengan baik.

Pada umumnya jenis perkerasan jalan yang digunakan di Indonesia adalah perkerasan kaku. Jika dilihat dari segi kekuatan, perkerasan kaku lebih kuat daripada perkerasan lentur, namun untuk memperbaiki kenyamanan harus dilakukan pelapisan dengan perkerasan lentur. Jenis lapis perkerasan lentur ada beberapa macam, salah satunya adalah aspal porous.

Aspal porous adalah aspal yang dicampur dengan agregat tertentu, yang mana setelah dipadatkan mempunyai $20 \%$ pori-pori udara (Setyawan dan Sanusi, 2008). Aspal 
porous umumnya memiliki nilai stabilitas Marshall lebih rendah dari pada aspal yang menggunakan gradasi rapat, stabilitas Marshall akan meningkat bila gradasi terbuka yang menggunakan fraksi halus lebih banyak (Cabrera \& Hamzah, 1994 d). Aspal porous merupakan jenis perkerasan berpori dengan campuran agregat kasar lebih dominan untuk meingkatkan gaya gesek dan mencegah terjadinya genangan pada permukaan jalan (Mukti, 2017). Aspal porous digunakan sebagai lapisan permukaan jalan sehingga memungkinkan air menembus perkerasan jalan melalui rongga di dalam campuran, dan dapat meningkatkan keselamatan lalu lintas terutama pada musim hujan.

Campuran aspal porous merupakan terobosan baru perkerasan lentur (Arlia, dkk, 2018). Aspal porous mampu menyerap air ke dalam lapisan atas (wearing course) baik secara vertikal maupun horizontal. Lapisan aspal porous menggunakan gradasi terbuka (open graded) yang dihamparkan diatas lapisan aspal kedap air. Lapisan aspal porous efektif memberikan tingkat keselamatan yang lebih, seperti ketika waktu hujan sehingga tidak terjadi aquaplaning yang menyebabkan kekesatan permukaan menjadi lebih kasar (Setyawan dan Sanusi, 2008). Saat ini banyak dilakukan penelitian penggunaan material alternatif untuk menggantikan material alam yang terbatas tersebut salah satunya penggunaan serbuk ban bekas.
Limbah Ban (ban bekas) merupakan salah satu bahan bekas pakai yang mudah ditemukan diseluruh wilayah dengan jumlah yang relatif cukup tinggi. Limbah ban kendaraan bermotor tidak dapat dipakai ulang serta tidak dapat larut dalam tanah, sehingga cukup berbahaya bagi lingkungan (Yamali, 2017). Salah satu upaya yang biasa dilakukan untuk mengurangi limbah ban kendaraan adalah pembakaran, namun proses pembakaran menghasilkan dampak polusi udara yang cukup berbahaya bagi lingkungan sekitar, terutama didaerah perkotaan yang padat penduduk (Hariyadi, dkk, 2018).

Beberapa jenis ban seperti jenis ban radial yang dicampur dengan karet sintetis jumlah karet alam yang digunakan dua kali lipat komponen karet alam untuk pembuatan ban non radial. Karet alam pada dasarnya mempunyai sifat fisik lembut, fleksibel, dan elastisserta mempunyai plastisitas yang baik, daya elastis yang sempurna, daya tahan dan daya lengket yang baik. US Department of Transportation Federal Highway Administration Amerika telah melakukan penelitian tentang penggunaan ban bekas sebagai bahan tambah (additive) dalam pembuatan aspal sejak tahun 1986. Hasilnya menunjukkan bahwa penggunaan hasil parutan ban bekas mampu mereduksi kerusakan pada perkerasan lentur yang disebabkan oleh faktor cuaca dan lalu lintas (Dina, dkk, 2019). Menurut Kennedy (2000) penggunaan penggunaan campuran parutan ban 
bekas sangat cocok jika digunakan pada daerah beriklim tropis.

Penggunaan serbuk ban bekas sebagai campuran pada agregat halus dalam penelitian ini diharapkan mampu memenuhi kebutuhan dalam perencanaan perkerasan lentur yang memiliki sifat elastisitas dan daya tahan yang tinggi terhadap keretakan serta mampu mengurangi limbah yang tidak dapat terurai secara alami. Dari segi teknis, pemanfaatan serbuk ban bekas sebagai pengganti agregat halus dapat menciptakan suatu perkerasan dengan kelenturan plastis yang tinggi. Perkerasan lentur memberikan kenyamanan lebih ketika berkendara dibandingkan perkerasan kaku.

Pelaksanaan penelitian ini dilakukan berdasarkan perbandingan volume untuk mempermudah dalam pelaksanaan pembuatan campuran agar campuran dapat masuk ke dalam mould, karena dengan volume dari ban yang besar, tetapi memiliki berat yang kecil. Dalam penelitian ini dilakukan kajian terhadap penggunaan material ban bekas untuk mengetahui kelayakannya dengan tujuan untuk menganalisis perencanaan campuran aspal porous dengan serbuk ban bekas sebagai campuran agregat halus, serta potensi yang dapat dihasilkan sebagai upaya pengolahan limbah ban bekas.

\section{METODE PENELITIAN}

Penelitian yang dilakukan adalah pengujian eksperimental. Pengujian eksperimental yang dilakukan adalah pengujian volumetric dan Marshall berdasarkan RSNI M-01-2003 dari benda uji campuran aspal porous dengan variasi persentase kadar serbuk ban bekas sebagai campuran agregat halus. Campuran aspal porous dirancang berdasarkan British Standard 1988. Variasi persentase kadar serbuk ban bekas sebagai campuran agregat halus berturut - turut adalah $0 \%, 4 \%, 6 \%, 8 \%$ dari berat agregat halus.

Jumlah benda uji yang digunakan pada penelitian adalah 3 buah benda uji untuk masing - masing variasi prosentase kadar serbuk ban bekas sebagai campuran agregat halus. Benda uji dengan kadar serbuk ban bekas sebagai campuran agregat halus sebesar $0 \%$ disebut sebagai benda uji campuran aspal porous normal. Hasil pengujian kemudian dibandingkan dengan Spesifikasi Umum Bina Marga 2018 .

\section{HASIL DAN PEMBAHASAN Densitas}

Hasil densitas dari masing-masing variasi benda uji dapat dilihat Tabel 1 . dan perbandingan densitas antara benda uji campuran aspal porous dengan serbuk ban bekas dan benda uji campuran aspal porous normal dapat dilihat pada Gambar 1 berikut:

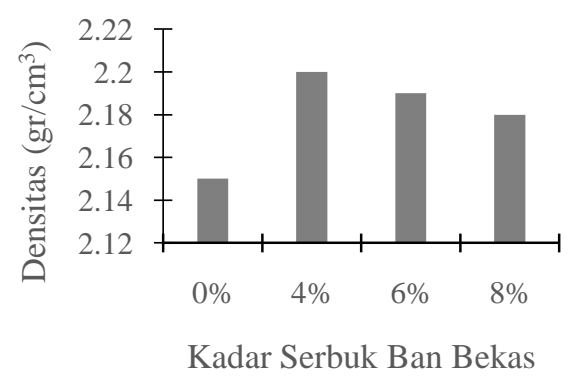

Gambar 1. Perbandingan densitas rata rata benda uji 
Dari hasil uji densitas diketahui bahwa densitas pada benda uji campuran aspal porous normal adalah sebesar $2.15 \mathrm{gr} / \mathrm{cm}^{3}$ dan densitas benda uji campuran aspal porous dengan serbuk ban bekas $4 \%, 6 \%, 8 \%$ berturut - turut adalah $2.20 \mathrm{gr} / \mathrm{cm}^{3}, 2.19$ $\mathrm{gr} / \mathrm{cm}^{3}, 2.18 \mathrm{gr} / \mathrm{cm}^{3}$. Hasil densitas benda uji dengan campuran serbuk ban bekas mengalami kenaikan sebesar $2.3 \%, 1.86 \%, 1.4 \%$ dari benda uji campuran aspal porous normal. Kenaikan densitas pada benda uji dengan campuran serbuk ban bekas terjadi karena kerapatan benda uji meningkat akibat penambahan serbuk ban bekas.

\section{Spesific Grafity Campuran}

Hasil spesific grafity campuran dari masing - masing variasi benda uji dapat dilihat Tabel 2 dan perbandingan spesific grafity campuran antara benda uji campuran aspal porous dengan serbuk ban bekas dan benda uji campuran aspal porous normal dapat dilihat pada Gambar 2 berikut:

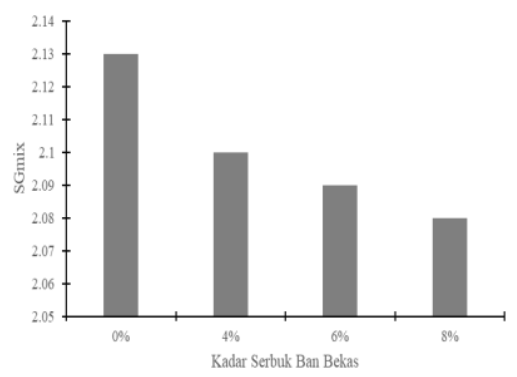

Gambar 2. Perbandingan spesific gravity campuran benda uji

Dari hasil uji spesific gravity campuran diketahui bahwa spesific gravity campuran pada benda uji campuran aspal porous normal adalah sebesar 2.13 dan spesific gravity campuran benda uji campuran aspal porous dengan serbuk ban bekas $4 \%$, $6 \%, 8 \%$ berturut - turut adalah 2.10 , $2.09,2.08$. Hasil spesific gravity campuran benda uji dengan campuran serbuk ban bekas mengalami penurunan sebesar $1.41 \%, 1.88 \%$, $2.35 \%$ dari benda uji campuran aspal porous normal. Penurunan nilai specific gravity campuran pada benda uji dengan campuran serbuk ban bekas dikarenakan semakin besarnya specific gravity komponen penyusun total. Dimana specific gravity komponen penyusun total berbanding terbalik terhadap nilai specific gravity campuran.

\section{Porousitas}

Hasil porousitas dari masing - masing variasi benda uji dapat dilihat Tabel 3 dan perbandingan porousitas antara benda uji campuran aspal porous dengan serbuk ban bekas dan benda uji campuran aspal porous normal dapat dilihat pada Gambar 3 berikut:

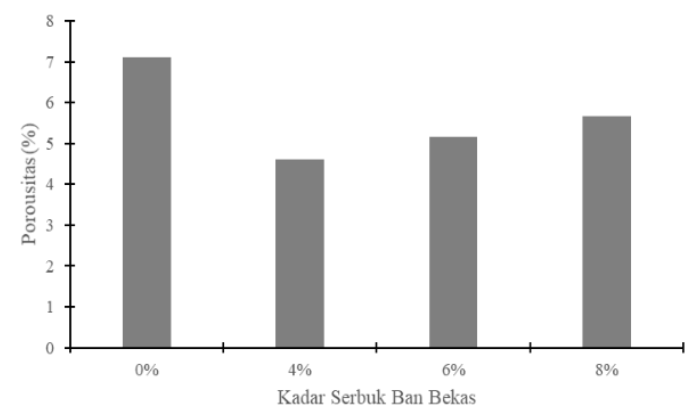

Gambar 3. Perbandingan porousitas benda uji

Dari hasil uji porousitas diketahui bahwa porousitas pada benda uji campuran aspal porous normal 
adalah sebesar $7.10 \%$ dan porousitas campuran benda uji campuran aspal porous dengan serbuk ban bekas $4 \%$, $6 \%, 8 \%$ berturut - turut adalah $4.60 \%$, $5.17 \%, 5.66 \%$. Hasil porousitas benda uji dengan campuran serbuk ban bekas mengalami penurunan sebesar $35.21 \%$, $27.18 \%, 20.28 \%$ dari benda uji campuran aspal porous normal. Penurunan porousitas pada benda uji dengan campuran serbuk ban bekas terjadi karena kandungan udara pada benda uji berkurang dengan penambahan serbuk ban bekas.

\section{Pengujian Marshall \\ Stabilitas}

Hasil stabilitas dari masing - masing variasi benda uji dapat dilihat Tabel 4 dan perbandingan stabilitas antara benda uji campuran aspal porous dengan serbuk ban bekas dan benda uji campuran aspal porous normal dapat dilihat pada Gambar 4 berikut:

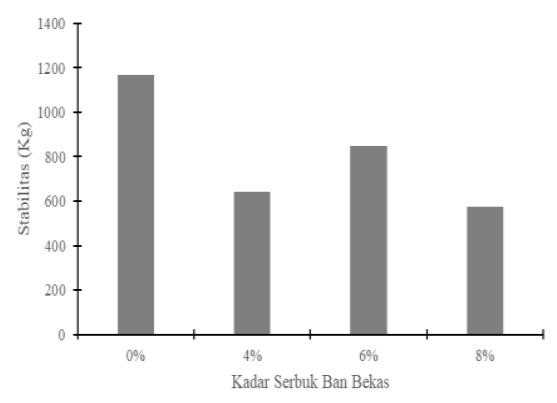

Gambar 4. Perbandingan stabilitas benda uji

Dari hasil uji stabilitas diketahui bahwa stabilitas pada benda uji campuran aspal porous normal adalah sebesar $1169.38 \quad \mathrm{Kg}$ dan stabilitas campuran benda uji campuran aspal porous dengan serbuk ban bekas $4 \%, 6 \%, 8 \%$ berturut - turut adalah $642.19 \mathrm{Kg}, 847.59 \mathrm{Kg}, 574.94$ Kg. Hasil stabilitas benda uji dengan campuran serbuk ban bekas mengalami penurunan dari benda uji campuran aspal porous normal, hal ini disebabkan karena serbuk ban bekas memiliki tingkat kekerasan (hardness) lebih rendah. Berdasarkan hasil uji stabilitas didapatkan bahwa benda uji dengan campuran serbuk ban bekas $6 \%$ dan benda uji campuran aspal porous normal yang memenuhi syarat dari campuran laston (AC) lapis aus dan lapis antara menurut Spesifikasi Umum Bina Marga 2018 untuk Pekerjaan Konstruksi Jalan dan Jembatan yaitu nilai minimal stabilitas adalah $800 \mathrm{~kg}$.

\section{Flow}

Hasil flow dari masing - masing variasi benda uji dapat dilihat Tabel 5 dan perbandingan flow antara benda uji campuran aspal porous dengan serbuk ban bekas dan benda uji campuran aspal porous normal dapat dilihat pada Gambar 5 berikut:

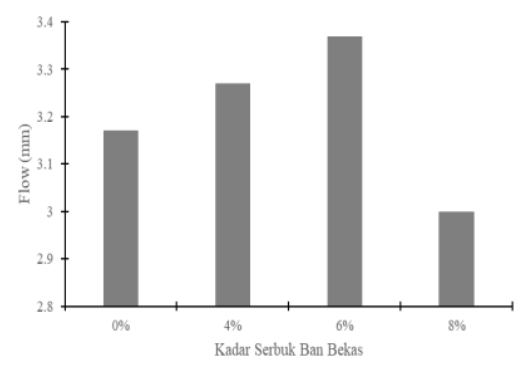

Gambar 5. Perbandingan flow benda uji

Dari hasil uji flow diketahui bahwa flowpada benda uji campuran aspal porous normal adalah sebesar $3.17 \mathrm{~mm}$ 
dan flow campuran benda uji campuran aspal porous dengan serbuk ban bekas $4 \%, 6 \%, 8 \%$ berturut - turut adalah $3.27 \mathrm{~mm}, 3.37 \mathrm{~mm}, 3 \mathrm{~mm}$. Hasil flow benda uji dengan campuran serbuk ban bekas mengalami kenaikan dari benda uji campuran aspal porous normal, hal ini disebabkan karena dengan menambahkan serbuk karet ban bekas akan mengakibatkan campuran aspal porous menjadi lebih elastis sehingga campuran aspal porous mampu menahan kelelahan plastis lebih baik daripada beton aspal porous normal. Berdasarkan hasil uji flow didapatkan bahwa semua benda uji memenuhi syarat dari campuran laston (AC) lapis aus dan lapis antara menurut Spesifikasi Umum Bina Marga 2018 untuk Pekerjaan Konstruksi Jalan dan Jembatan yaitu nilai flow adalah $2-4$ $\mathrm{mm}$.

\section{Marshall Quotient}

Hasil Marshall Quotient dari masing masing variasi benda uji dapat dilihat Tabel 6 dan perbandingan Marshall Quotient antara benda uji campuran aspal porous dengan serbuk ban bekas dan benda uji campuran aspal porous normal dapat dilihat pada Gambar 6 .

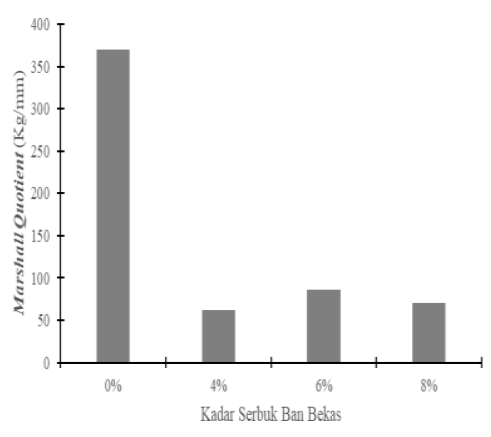

Gambar 6. Perbandingan marshall quotient benda uji
Dari hasil uji Marshall Quotient diketahui bahwa Marshall Quotient pada benda uji campuran aspal porous normal adalah sebesar $369.3 \mathrm{Kg} / \mathrm{mm}$ dan Marshall Quotient campuran benda uji campuran aspal porous dengan serbuk ban bekas $4 \%, 6 \%, 8 \%$ berturut - turut adalah $61.6 \mathrm{Kg} / \mathrm{mm}$, $85.8 \mathrm{Kg} / \mathrm{mm}, 70.1 \mathrm{Kg} / \mathrm{mm}$. Hasil Marshall Quotient benda uji dengan campuran serbuk ban bekas mengalami penurunan dari benda uji campuran aspal porous normal. Dengan adanya penambahan limbah ban bekas akan mengakibatkan penurunan nilai stabilitas campuran dan naiknya flow. Apabila stabilitas turun dan flow naik akan menyebabkan turunnya nilai Marshall Quotient karena stabilitas dan flow hubungannya berbanding terbalik.

\section{Kekesatan Permukaan}

Untuk pengujian kekesatan ini hanya dilakukan untuk 2 macam benda uji yaitu pengujian kekesatan benda uji aspal porous normal dan benda uji dengan campuran serbuk ban bekas $6 \%$, dimana benda uji dengan campuran serbuk ban bekas $6 \%$ yang memenuhi syarat Spesifikasi Umum Bina Marga 2018. Hasil uji kekesatan permukaan dapat dilihat pada Tabel 7.

Tabel 1. Kekesatan Permukaan Benda

\begin{tabular}{cccc}
\multicolumn{3}{c}{ Uji } \\
\hline No. & Kode & British & Mu Meter \\
& Benda & Pendulum \\
& Uji & Number & \\
\hline 1 & $0 \%$ & 73.4 & 0.55 \\
2 & $6 \%$ & 86.4 & 0.68 \\
\hline
\end{tabular}


Berdasarkan hasil uji dapat dilihat bahwa nilai kekesatan dari aspal porous dengan serbuk ban bekas sebagai pengganti agregat halus mengalami kenaikan sebesar $17,71 \%$. Nilai Mu-Meter dari benda uji nilainya memenuhi Peraturan Menteri Pekerjaan Umum No. 16/PRT/M/2014 yaitu lebih besar dari $0.33 \mathrm{Mu}-$ Meter.

\section{Perkiraan Besaran Serbuk Ban Bekas pada Pekerjaan Konstruksi Perkerasan Jalan}

Berdasarkan hasil pengujian nilai campuran serbuk ban bekas pada agregat halus campuran aspal porous yang memenuhi syarat untuk digunakan pada pekerjaan konstruksi jalan menurut Spesifikasi Umum Bina Marga 2018 adalah 6\%. Sehingga nilai kadar 6\% serbuk ban bekas pada agregat halus campuran aspal porous ini digunakan untuk menghitung perkiraan besaran serbuk ban bekas pada pekerjaan konstruksi perkerasan jalan. Berdasrkan kadar tersebut dapat dihitung presentase serbuk ban bekas pada total campuran aspal porous adalah sebesar 1,2\%. Perhitungan mengunakan data sebagai berikut, ketebalan lapisan aus perkerasan $4 \mathrm{~cm}$, lebar jalan $7 \mathrm{~m}$, dan panjang jalan 1 km. Ketebalan lapis aus perkerasan didapatkan dari ketebalan mimimum untuk laston lapis aus berdasarkan Spesifikasi Umum Bina Marga 2018. Lebar jalan didapatkan dari jalan dua lajur dua arah dengan masing - masing jalur mempunyai lebar 3,5 m.

Berdasarkan data tersebut didapatkan jumlah volume lapis aus perkerasan total adalah $280 \mathrm{~m}^{3}$.
Kemudian didapatkan volume serbuk ban bekas yang digunakan adalah 3,36 $\mathrm{m}^{3}$. Dari volume tersebut dapat dihitung berat serbuk ban bekas yang digunakan berdasarkan berat jenis karet 0,902 $\mathrm{gr} / \mathrm{cm}^{3}$ adalah 3,03 ton. Hasil penelitian ini didapatkan penggunaan serbuk ban bekas dapat mengurangi limbah ban bekas sebesar 3,03 ton per $1 \mathrm{~km}$ pekerjaan konstruksi perkerasan jalan. Sehingga penelitian ini dirasa cukup menjadi solusi dalam menangani permasalahan lingkungan yaitu pengolahan limbah ban bekas. Sebagai rekomendasi bahan penelitian berikutnya dapat dilakukan campuran pada agregat yang lain dengan beberapa variasi.

\section{SIMPULAN}

Berdasarkan hasil pengujian yang telah dilakukan, nilai Marshall Properties pada campuran aspal porous dengan serbuk ban bekas dapat disimpulkan bahwa yang memenuhi syarat Spesifikasi Umum Bina Marga 2018 dan kekesatan permukaan yang memenuhi syarat Peraturan Menteri Pekerjaan Umum No. 16/PRT/M/2014 adalah campuran aspal porous dengan campuran serbuk ban bekas 6\% dan campuran aspal porous normal. Hasil dari penelitian ini juga dapat bahwa penggunaan serbuk ban bekas dapat mengurangi limbah ban bekas sebesar 3,03 ton per $1 \mathrm{~km}$ pekerjaan konstruksi perkerasan jalan.

\section{UCAPAN TERIMA KASIH}

Ucapan terima kasih kami sampaikan kepada Jurusan Teknik Sipil Politeknik Negeri Jakarta yang selalu 
memberikan dukungan sehingga artikel ini dapat terselesaikan.

\section{DAFTAR PUSTAKA}

Arlia, L., Saleh, S., M., Anggraini, R., 2018, Karakteristik Campuran Aspal Porus dengan Substitusi Gondorukem pada Aspal Penetrasi 60/70, Jurnal Teknik Sipil Universitas Syiah Kuala, Volume 1 Special Issue, Nomor 3, Januari, 2018, pp. 657 - 666, Doi : $10.24815 /$ jts.v1i3.10011

Badan Pusat Statistik, 2019, Perkembangan Jumlah

Kendaraan Bermotor menurut Jenis Tahun 1949-2017

https://www.bps.go.id/linkTable Dinamis/view/id/1133

British Standards Institution, 1988, Coated macadam for roads and other paved areas: Part 1, Specification for constituent materials and for mixtures, BS 4987, Part 1, London, British Standards Institution

Cabrera, J.G. \& Hamzah, M.O., 1994, Aggregate Grading Design For Porous Asphalt, In Cabrera, J.G. \& Dixon, J.R. (eds), "Performance and Durability of Bituminous Materials", Proceeding of Symposium, University of Leeds, March 1994, London

Dina, F., Saleh, S. M., Suryani, F. M., 2019, Karakteristik Penggunaan Parutan Ban Dalam Bekas Kendaraan Roda 4 Terhadap Campuran AC-BC, Journal of The Civil Engineering Student,
Vol. 1, No. 1, April 2019, Hal. 1-7

Hariyadi, H., Pratama, Y., Sigit, Fadhilah, L., Maryunani, W.P., Sudarno, 2018, Pengaruh Ukuran Crumb Rubber Mesh \#80 dan Mesh \#120 (Serbuk Limbah Ban Karet) pada Penambahan Campuran Laston untuk Perkerasan Jalan, Reviews in Civil Engineering, Vol. 02, No. 2, September 2018, pp. 8285

Kennedy, 2000, Characterization of Asphalt Pavement Material Using the Indirect Tensile Strength, Proceeding Association of Asphalt Paving Technology, Volume 46, Center for Transportation Research The University of Texas, San Antonio, USA

Mukti, A. S., 2017, Analisis Pengaruh Substitusi Asbuton Lga (Lawele Granular Asphalt) Pada Aspal Penetrasi 60/70 Terhadap Campuran Aspal Porus, Rekayasa Teknik Sipil, Vol. 01 Nomor 01/Rekat/17, pp. 381 387

Peraturan Menteri Pekerjaan Umum

No. 16/PRT/M/2014, tentang

Standar Pelayanan Minimal Jalan Tol

RSNI M-01-2003, Metode pengujian campuran beraspal panas dengan alat marshall

Setyawan, Ary dan Sanusi, 2008, Observasi Properties Aspal Porus Berbagai Gradasi dengan Material Lokal, MEDIA 
TEKNIK SIPIL, Januari 2008, pp. $15-20$

SNI 4427 : 2008. Cara Uji Kekesatan Permukaan Perkerasan Menggunakan Alat British Pendulum Tester (BPT)

Sugiyanto, G., 2008., Kajian Karakteristik Campuran Hot Rolled Asphalt Akibat Penambahan Limbah Serbuk Ban Bekas, Jurnal Teknik Sipil, Volume 8, No. 2, Februari 2008, pp. 91-104

Surat Edaran Dirjen Bina Marga No. 02/SE/Db/2018, tentang
Spesifikasi Umum Bina Marga 2018 untuk Pekerjaan Konstruksi Jalan dan Jembatan Yamali, F. R., 2017, Pengaruh Penambahan Limbah Karet Ban Luar pada Lapis Tipis Aspal Pasir (Latasir) Terhadap Karakteristik Marshall, Jurnal Civronlit Universitas Batanghari, Vol.2 No.2, Oktober 2017, pp. 54-63. DOI: http://dx.doi.org/10.33087/ civronlit.v2i2.25 